\title{
PEMBUATAN MEDIA PEMBELAJARAN MATEMATIKA DAN IPA YANG TERINTEGRASI DENGAN NILAI BUDAYA LOKAL PADA SMP YPK TOMER
}

\author{
Supriyadi $^{1)}$, Andi Saparuddin Nur ${ }^{2)}$ \\ Fakultas Keguruan dan Ilmu Pendidikan, Universitas Musamus \\ supriyadi_fkip@unmus.ac.id ${ }^{1)}$, andisaparuddin@unmus.ac.id ${ }^{2)}$
}

\begin{abstract}
SMP YPK Tomer is located in Naukenjerai District, where the majority of the population is indigenous Papuans, the Kanum Tribe. Most SMP YPK Tomer students have a way of thinking, and a lifestyle that is still very thick with the cultural principles that develop in their community. The purpose of this training is to provide education and equip math and science teachers at SMP YPK Tomer with the skills to choose and design mathematics and science learning media that are integrated with local cultural values (in this case the Kanum tribe associated with Kampung Tomer). Training and mentoring are designed using ethnomatematics and etnosains which are learning mathematics and science by involving local cultural values. The results of this service are obtained: ruler and protractor media, spatial structure, simple conductivity test material, and air purifier. The response strongly agrees that students are given the learning media for the readability criteria of $87 \%$, the free criteria are used at $73 \%$, and the accessibility criteria is $81 \%$.
\end{abstract}

Keywords: learning media, mathematics, science, local culture

\begin{abstract}
Abstrak
SMP YPK Tomer terletak di Distrik Naukenjerai yang sebagian besar penduduknya adalah masyarakat asli Papua yaitu Suku Kanum. Sebagian besar siswa SMP YPK Tomer memiliki cara berpikir, dan pola hidup yang masih sangat kental dengan prinsip budaya yang berkembang di komunitasnya. Tujuan pelatihan ini adalah memberikan edukasi dan membekali guru matematika dan IPA pada SMP YPK Tomer dengan keterampilam memilih dan mendesain media pembelajaran matematika dan IPA yang terintegrasi dengan nilai budaya lokal setempat (dalam hal ini suku Kanum yang menempati wIlayah Kampung Tomer). Pelatihan dan pendampingan ini dirancang dengan menggunakan pendekatan etnomatematika dan etnosains yang merupakan pendekatan pembelajaran matematika dan IPA dengan melibatkan nilai budaya lokal setempat. Hasil kegiatan pengabdian ini diperoleh: media penggaris dan busur derajat, rangka bangun ruang, uji konduktivitas bahan sederhana, serta alat penjernih air. Respon sangat setuju yang diberikan siswa terhadap media pembelajaran untuk kriteria keterbacaan sebesar $87 \%$, kriteria kemudahan digunakan sebesar $73 \%$, dan kriteria aksesibilitas sebesar $81 \%$.
\end{abstract}

Kata Kunci: media pembelajaran, matematika, IPA, budaya lokal

\section{PENDAHULUAN}

SMP YPK Tomer terletak di Kampung Tomer, Distrik Naukenjerai terletak sekitar $50 \mathrm{Km}$ dari Kota Merauke. SMP YPK Tomer merupakan salah satu sekolah di bawah Yayasan Pendidikan Kristen (YPK) di Tanah Papua dan satu- satunya sekolah menengah pertama di Distrik Naukenjerai. Seluruh siswa yang terdaftar di SMP YPK Tomer merupakan lulusan dari SD di lima kampung se Distrik Naukenjerai dan sebagian besar merupakan anak Suku Kanum. Jumlah siswa SMP YPK Tomer sampai pada 
bulan Maret 2018 berjumlah 93 orang dengan jumlah guru sebanyak 10 . Sementara itu, setiap jenjang kelas hanya terdiri atas satu kelas paralel.

Permasalahan yang dijumpai pada siswa SMP YPK Tomer adalah masih rendahnya daya serap memahami materi matematika dan IPA. Nilai ulangan harian dan ujian tengah semester menunjukkan $75 \%$ siswa belum mencapai Kriteria Ketuntasan Minimal (KKM). Berdasarkan hasil observasi dengan guru matematika SMP YPK Tomer diketahui bahwa faktor penyebab masih rendahnya kemampuan belajar matematika siswa disebabkan belum tersedianya media pembelajaran yang memadai dalam menunjang aktivitas proses belajar mengajar. Kesulitan guru dalam menyediakan media pembelajaran adalah masih kurangnya program pelatihan atau pendampingan pembuatan media baik yang diselenggarakan oleh dinas pendidikan maupun instansi lainnya. Guru masih menggunakan buku teks pelajaran sebagai bahan ajar utama di dalam kelas sehingga siswa terkadang belum mampu memahami isi materi yang diajarkan.

Proses pembelajaran siswa sangat bergantung pada pemahaman materi yang disampaikan oleh guru, sehingga muatan materi yang diajarkan seringkali berbeda jauh dengan kondisi nyata yang ada di sekitar siswa. Siswa seringkali bingung dan tidak mampu memahami suatu konsep yang dicontohkan karena tidak pernah menjumpai hal tersebut. Akibatnya, siswa tidak dapat menemukan manfaat dari belajar matematika maupun IPA. Sebagai contoh, siswa tidak mampu memahami konsep pemfaktoran bentuk aljabar disebabkan sifat objeknya yang sangat abstrak. Memasukkan unsur kebudayaan dalam pembelajaran IPA dan Matematika selain dapat meningkatkan pemahaman siswa, juga dapat menjadi sarana pelestarian budaya lokal (Kencanawaty \& Irawan, 2017).

Hal demikian juga dirasakan siswa saat mempelajari materi IPA yang memerlukan berbagai bentuk kegiatan praktikum. Berdasarkan informasi dari guru IPA diketahui bahwa pembelajaran dengan kegiatan praktikum masih jarang dilakukan karena alat yang dibutuhkan masih sangat terbatas. Sebagai contoh pada materi perubahan wujud zat, guru hanya menyampaikan informasi melalui buku teks sehingga siswa terkesan dipaksa menghafal konsep. Padahal jika pembelajaran dilakukan dengan berbagai kegiatan praktikum, siswa akan lebih mampu memahami keterkaitan konsep yang dipelajari dengan penerapannya dalam kehidupan sehari-hari.

Proses pembelajaran yang bermakna merupakan inti dari keberhasilan pencapaian kompetensi. Siswa akan lebih mampu memahami materi jika disampaikan secara kontekstual dan dikembangkan melalui situasi sosial nyata di lingkungan sekitar siswa. Siswa SMP YPK Tomer yang sebagian besar merupakan anak Suku Kanum memiliki berbagai kebudayaan lokal secara turun temurun. Pembelajaran dengan mengintegrasikan nilai budaya merupakan salah satu upaya mengembangkan keterampilan hidup siswa agar mampu beradaptasi dengan 
lingkungan sekitarnya (Rohaeti, 2011). Pengintegrasian antara sosial budaya dan pembelajaran disekolah dapat meningkatkan minat dan motivasi belajar siswa yang akhirnya dapat meningkatkan hasil belajar siswa (Supriyadi, Haeruddin, \& Nurjannah, 2016). Contoh kebudayaan Suku Kanum yang dapat diintegrasikan dengan materi pembelajaran adalah konsep perhitungan, konsep pengukuran, konsep bangun ruang, konsep suhu dan kalor, konsep listrik dan konsep perubahan zat. Selain permasalahan keterbatasan media pembelajaran, faktor sulitnya medan menuju SMP YPK Tomer juga menjadi rintangan dalam menyediakan akses pengembangan media pembelajaran oleh guru. Pada musim hujan, untuk dapat sampai ke sekolah memerlukan berbagai persiapan baik dari segi kendaraan maupun kelengkapan lainnya sehingga tidak dimungkinkan membawa media pembelajaran dari Kota ke sekolah. Selain itu, pada musim kemarau, kondisi jalan semakin diperparah dengan banyaknya truk pengangkut pasir yang dapat membahayakan jika membawa banyak barang bawaan khususnya media pembelajaran. Oleh karena itu, guru perlu mengembangkan secara mandiri media pembelajaran khususnya untuk mata pelajaran matematika dan IPA. Pembelajaran dengan menggunakan media akan membuat siswa lebih mudah dalam menangkap apa yang ingin dijelaskan pembelajar (Rahayu \& Sutikno, 2015). Sehingga penggunaan media menjadi sebuah keharusan. Hal tersebut hanya dapat tercapai jika guru dibekali wawasan mengembangkan media pembelajaran melalui pelatihan serta pendampingan pembuatan media pembelajaran di sekolah.

Lebih jauh permasalahan yang dihadapi adalah masih sangat kurangnya guru yang dilibatkan dalam berbagai pelatihan untuk peningkatan kompetensi. Informasi yang diperoleh dari guru bahwa pengembangan kapasitas berupa pelatihan pembuatan media pembelajaran belum banyak dilakukan. Hal tersebut berakibat pada kurangnya rasa percaya diri guru untuk membuat berbagai media pembelajaran yang dapat membantu siswa dalam mempelajari konsep matematika dan IPA. Penggunaan buku teks yang tidak mencukupi dengan keterbatasan guru dalam mengembangkan media pembelajaran berdampak pada kemampuan siswa belajar matematika dan IPA. Siswa merasa cepat bosan dan tidak tertarik mempelajari matematika dan IPA meskipun berbagai konsep dalam matematika dan IPA memiliki keterkaitan dengan konteks kehidupan sehari-hari. pembelajaran dengan modul IPA berbasis kearifan lokal menciptakan kesan pembelajaran kontekstual pada siswa (Saputra, Wahyuni, \& Handayani, 2016). Hal tersebut dapat ditinjau pada berbagai aplikasi konsep matematika dan IPA yang telah diterapkan dalam beberapa perilaku kehidupan Suku Kanum yang menjadi identitas asli siswa SMP YPK Tomer. Oleh karena itu, perlu dilakukan pendampingan berupa pelatihan serta pembuatan media pembelajaran yang mengintegrasikan nilai budaya lokal pada SMP YPK Tomer sebagai upaya meningkatkan 
pemahaman siswa dalam mempelajari konsep matematika dan IPA.

\section{METODE PELAKSANAAN}

Tahapan awal kegiatan pengabdian ini akan dijelaskan melalui bagan berikut:

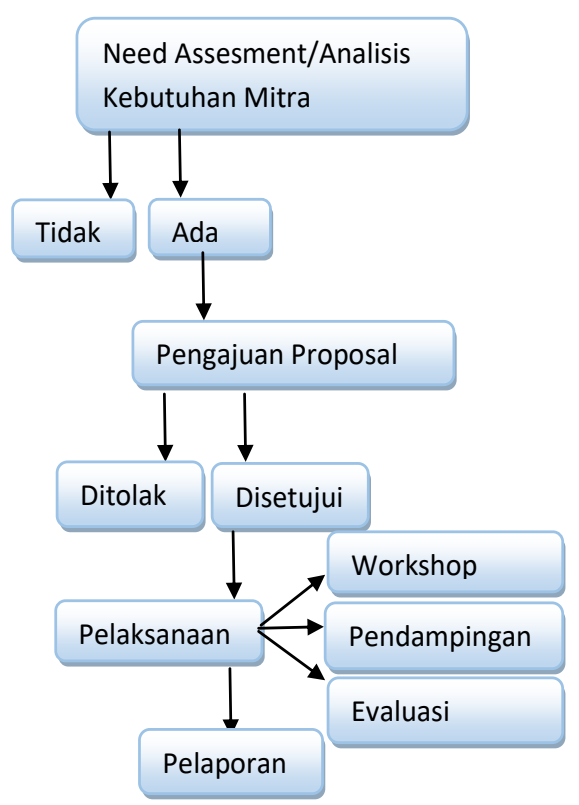

Gambar 1. Tahapan Pelaksanaan kegiatan pengabdian

Metode pelaksanaan dalam kegiatan pengabdian ini dibedakan atas tiga kegiatan utama, yaitu:

\section{Workshop}

Pada kegiatan ini, dilakukan workshop berupa pelatihan pembuatan media pembelajaran matematika dan IPA bersama guru SMP YPK Tomer. Peserta workshop berjumlah 20 orang yang terdiri atas guru, pemateri, dan mahasiswa. Pelaksanaan workshop dilaksanakan di ruang kelas SMP YPK Tomer dengan tujuan agar dapat diperoleh pemetaan materi yang memerlukan media pembelajaran matematika dan IPA yang terintegrasi nilai budaya lokal. Melalui pemetaan materi, desain media pembelajaran dapat dirancang sesuai kebutuhan siswa sehingga lebih efektif, praktis dan efisien penggunaannya.

\section{Pendampingan}

Kegiatan pendampingan dilaksanakan dalam dua tahap. Tahap pertama dilakukan pendampingan pembuatan media pembelajaran matematika dan tahap kedua dilakukan pendampingan pembuatan media pembelajaran IPA. Pendampingan bertujuan agar guru dapat mengetahui teknis pembuatan media pembelajaran baik dari aspek teori maupun praktik penggunaannya.

3. Evaluasi produk kegiatan

Kegiatan terakhir adalah evaluasi produk yang dihasilkan dari kegiatan pengabdian berupa pengkajian tentang keefektifan, kepraktisan, dan kevalidan 
media pembelajaran. Tim pengabdian membagikan kuesioner kepada siswa SMP YPK Tomer tentang penggunaan media pembelajaran yang dihasilkan. Setelah diperoleh hasil evaluasi kegiatan, tim pengabdian akan merefleksikan capaian yang telah diperoleh dan merekomendasikan upaya tindak lanjut berikunya.

\section{HASIL DAN PEMBAHASAN}

Kegiatan pembuatan media pembelajaran matematika dan IPA berbasis kearifan budaya lokal di SMP YPK Tomer dibedakan melalui tiga tahapan utama, yaitu:

\section{Tahap persiapan}

Pada tahap persiapan, tim melakukan permohonan perizinan kepada Kepala Dinas Pendidikan dan Kebudayaan Kabupaten Merauke dan Kepala SMP YPK Tomer pada tanggal 20 Oktober 2018. Tim menyampaikan usul kegiatan serta maksud dan tujuan dilaksanakannya pembuatan media pembelajaran di SMP YPK Tomer. Kepala sekolah menyambut baik usulan tersebut dan memberikan masukan terkait pelaksanaan kegiatan di sekolah. Hasil diskusi bersama kepala sekolah diperoleh rencana pelaksanaan kegiatan dimulai pada minggu terakhir bulan oktober sampai bulan november dan pemaparan berupa workshop serta sosialisasi media di sekolah pada minggu pertama bulan Desember 2018.

Rencana pembuatan media pembelajaran berupa media penggaris dan busur derajat dari kayu lokal di Kampung Tomer, rangka bangun ruang (kubus, balok, dan prisma) dari besi, rangka bangun ruang setengah bola dari tempurung kelapa, rangkaian konduktor isolator listrik, dan alat penjernih air. Pembuatan media pembelajaran difokuskan pada alat-alat yang mudah dijumpai di sekitar lingkungan sekolah dengan memperhatikan aspek keefektifan, dan efisiensi penggunaan media.

Pemilihan alat dan bahan yang digunakan dalam membuat media pembelajaran didiskusikan bersama guru mata pelajaran matematika dan IPA. Berdasarkan hasil diskusi maka diperoleh alat yang dianggap tepat dan mampu mengkonstruksi media pembelajaran secara tepat serta dapat diperoleh dengan mudah. Selain itu, aspek murah juga menjadi pertimbangan tim disebabkan siswa SMP YPK Tomer didominasi oleh putra daerah sehingga aspek biaya menjadi penting agar tidak memberatkan siswa pada saat menyusun media pembelajaran tersebut secara mandiri.

2. Tahap pembuatan media pembelajaran

a. Penggaris dan busur derajat Penggaris dan busur derajat merupakan alat yang sering digunakan guru dalam mengajarkan materi geometri dan pengukuran. Penggaris memiliki fungsi sebagai instrumen ukur satuan panjang yang biasa dinyatakan sebagai satuan sentimeter $(\mathrm{cm})$ atau inch. Selain itu, penggaris juga biasa digunakan oleh guru dalam menggambar desain suatu bangun datar atau bangun ruang. 
Sedangkan busur derajat merupakan alat yang digunakan untuk mengetahui besaran suatu sudut. Sudut merupakan daerah yang terbentuk oleh akibat bertemunya dua buah garis atau sinar dan berpotongan pada suatu titik. Busur derajat sangat penting peranannya dalam mengukur sudut pada bidang datar bahkan dapat digunakan untuk mengetahui panjang garis pada objekobjek geometri lainnya.

\section{b. Rangka bangun ruang}

Bangun ruang merupakan materi yang diajarkan kepada siswa sejak masih SD dan berlanjut pada jenjang SMP. Materi bangun ruang di jenjang SMP memiliki tingkat abstraksi yang lebih tinggi sehingga bagi siswa dengan keterbatasan pemahaman visual spasial membutuhkan media pembelajaran. Pengembangan media yang dapat digunakan untuk memberikan pemahaman konsep bangun ruang adalah rangka bangun ruang yang terbuat dari besi batangan. Besi batangan merupakan bahan yang mudah dijumpai di lingkungan sekitar sekolah disebabkan besi tersebut merupakan bekas besi pagar. Penggunaan besi batangan juga memberikan dampak awet terhadap media yang digunakan serta dapat digunakan untuk ilustrasi konsep geometri lainnya seperti jaring-jaring bangun ruang.

Pembuatan rangka bangun ruang menggunakan besi difokuskan pada bangun ruang sisi datar seperti kubus, balok, prisma, dan limas. Rangka bangun ruang dikonstruksi untuk memperoleh gambaran rusuk, diagonal bidang, diagonal ruang, serta bidang diagonal menggunakan plat besi.

Pada saat pembuatan model rangka bangun ruang, terdapat saran dari guru mata pelajaran matematika agar menambahkan diagonal bidang pada setiap elemen kubus/balok menggunakan tali dari serabut pisang. Hal tersebut dimaksudkan agar siswa menjadi lebih paham jumlah diagonal bidang pada kubus/balok karena jika hanya diwakili oleh satu diagonal bidang saja siswa belum paham. Meskipun menggunakan potongan besi, hal tersebut akan berdampak tidak efektif pada penggunaan media sehingga unsur kearifan lokal dapat menjadi alternatif agar siswa dapat mudah memahami konsep tersebut.

\section{c. Rangka bangun ruang sisi lengkung}

Konsep bangun ruang sisi lengkung merupakan konsep yang telah teraplikasi dalam masyarakat suku di Kampung Tomer. Misalnya bangun ruang kerucut yang dapat dijumpai dalam bentuk musamus (rumah rayap) di Kampung Tomer, bangun ruang tabung yang menyerupai tifa (alat musik masyarakat Tomer), atau bangun ruang setengah bola yang menyerupai honai (rumah tradisional masyarakat Tomer).

Penggunaan bahan untuk membuat bangun ruang sisi lengkung dipilih batok/tempurung kelapa sebagai media. Kampung Tomer yang terletak di pinggiran pantai menyebabkan banyak terdapat pohon kelapa yang biasa digunakan oleh masyarakat sebagai sumber penghasilan. Tempurung kelapa 
banyak dijumpai di Kampung Tomer dan memiliki aneka bentuk yang menyerupai bola bahkan berbentuk lonjong yang jika dibelah dapat berbentuk kerucut.

\section{d. Rangkaian uji konduktivitas sederhana}

Listrik merupakan konsep abstrak dalam pikiran siswa SMP YPK Tomer disebabkan listrik baru masuk kampung sekitar 2 tahun yang lalu. Listrik hanya dipahami oleh siswa sebagai strom atau colokan yang ada di setiap rumah mereka. Guru mata pelajaran IPA mengalami kesulitan dalam memberikan pemahaman kepada siswa tentang konsep listrik serta pengembangan media yang tepat untuk mengajarkan hal tersebut. Oleh karena itu, tim memilih rangkaian alat uji konduktivitas sederhana sebagai media pembelajaran yang dapat memberikan gambaran tentang konsep listrik kepada siswa.

Bahan yang dipilih untuk bahan konduktor, isolator difokuskan pada keterjangkauan alat/bahan baik dari segi harga maupun akses pemerolehannya. Selain itu, alat/bahan yang digunakan sedapat mungkin dapat dikonstruksi ulang di rumah sehingga siswa dapat mempelajari konsep listrik yang ada di lingkungan sekitar.

\section{e. Alat penjernih air}

Kampung Tomer terletak di daerah pesisir Distrik Naukenjerai Kabupaten Merauke dan memiliki masalah dalam masalah air bersih. Air sumur pada saat musim kemarau banyak yang mengalami keruh serta menyebabkan berbagai masalah kesehatan seperti gatal-gatal dan penyakit kulit lainnya. Potensi sumber daya alam yang terdapat di Kampung Tomer merupakan aset berharga yang wajib dimanfaatkan. Oleh karena itu, tim melakukan pembuatan simulasi alat penjernih air di dalam kelas menggunakan botol plastik bekas sehingga dapat memberikan gambaran umum kepada siswa tentang penjernihan air secara massal. Bahan yang digunakan pada umumnya telah ada di sekitar siswa misalnya, sabuk kelapa, ijuk, pasir, kerikil, arang, dan saringan lainnya yang bersifat sebagai penjernih.

\section{Tahap sosialisasi}

Tahapan berikutnya adalah tahap sosialisasi yang dilaksanakan dalam bentuk wokshop. Pelaksanaan kegiatan sosialisasi pada hari rabu tanggal 28 November 2018 dengan melibatkan seluruh guru dan siswa SMP YPK Tomer. Workshop pembuatan media pembelajaran dibedakan dalam dua sesi, yaitu (1) pengenalan singkat tentang pentingnya media pembelajaran, dan (2) simulasi pembuatan dan penggunaan media pembelajaran.

Tahap pengenalan pentingnya media pembelajaran melibatkan seluruh guru SMP YPK Tomer dengan pendekatan presentasi melalui powerpoint disertai tanya jawab. Antusiasme guru SMP YPK Tomer dalam mengikuti kegiatan workshop sangat tinggi ditandai dengan kehadiran seluruh guru dalam kegiatan pentingnya media pembelajaran meskipun media yang dimaksud terbatas pada media pembelajaran matematika dan IPA. Selain itu, minat guru dalam mengenal berbagai bentuk media 
pembelajaran tergolong tinggi dengan banyaknya pertanyaan guru terkait cara mengembangkan media pembelajaran dengan sumber daya yang terbatas.

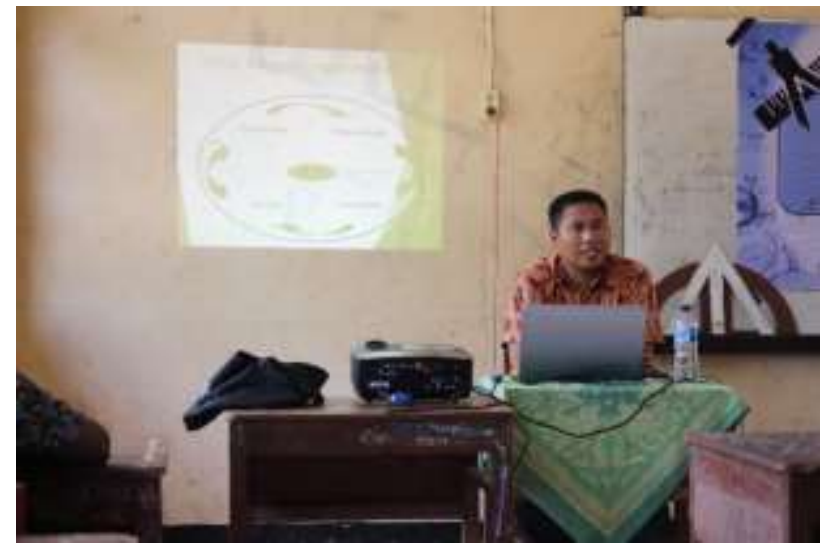

Gambar 2. Presentasi materi workshop

Tim pengabdian menjelaskan bahwa pengembangan media pembelajaran tidak selamanya memerlukan biaya yang besar. Media pembelajaran dapat dikonstruksi dengan memanfaatkan berbagai alat/bahan yang mudah diperoleh di lingkungan sekitar sekolah. Bahkan lingkungan sekitar sekolah dapat dimanipulasi menjadi media pembelajaran yang interaktif dan berbasis lingkungan. Pemanfaatan berbagai potensi di sekitar lingkungan siswa merupakan sarana efektif yang dapat membantu siswa memahami materi yang diberikan. Guru tidak semestinya selalu berpikir membuat media akan mengeluarkan biaya, namun mencoba mengembangkan media yang murah dan ramah lingkungan merupakan inti dari ketercapaian kompetensi pembelajaran yang efektif dan menyenangkan.

Pada sesi kedua, tim melakukan simulasi berbagai media pembelajaran yang telah dihasilkan bersama guru mata pelajaran matematika dan IPA. Simulasi media pembelajaran melibatkan guru bersama siswa dengan harapan diperoleh rancangan final atas media yang telah dihasilkan. Simulasi pertama dilakukan dengan mengenalkan cara pembuatan dan penggunaan penggaris serta busur derajat. Ternyata, diperoleh fakta bahwa masih banyak siswa SMP YPK Tomer yang belum mampu mengukur satuan panjang dan sudut dengan baik. Bahkan untuk penggunaan busur derajat masih banyak yang mengalami kebingungan.

Pengenalan unsur-unsur bangun ruang juga mendapatkan perhatian yang tinggi dari siswa. Berdasarkan hasil simulasi, diperoleh fakta bahwa hampir seluruh siswa SMP YPK Tomer belum mampu membedakan perbedaan diagonal bidang, diagonal ruang, dan bidang diagonal. Melalui presentasi simulasi media secara perlahan persepsi siswa mulai terbentuk dan mampu memberikan abstraksi yang tepat mengenai konsep tersebut. 
Simulasi selanjutnya adalah pengenalan pembuatan media pembelajaran IPA, yaitu simulasi rangkaian uji konduktivitas sederhana serta alat penjernih air. Perhatian siswa sangat tinggi, terutama pada saat simulasi uji konduktivitas sederhana. Tampak bahwa siswa sangat tertarik mempelajari sesuatu yang baru namun langsung teraplikasi. Siswa dengan cekatan melakukan rangkaian konduktor dan isolator secara bergantian dan mampu memahami prinsip kerja listrik.

Media pembelajaran yang telah dihasilkan diberikan penilaian oleh siswa untuk mengetahui tingkat keterbacaan media, tingkat kemudahan penerapan media, dan tingkat aksesibilitas penggunaan media (Kurniawan, Sarwanto, \& Cari, 2013; Mannan, Sopyan, \& Sunarno, 2015; Rahayu \& Sutikno, 2015; Saputra et al., 2016). Penilaian diberikan siswa dengan menggunakan lembar angket berisi pernyataan dan siswa memberikan respon berupa sikap setuju atau tidak setuju dengan pernyataan tersebut. hasil respon siswa selengkapnya dilihat pada gambar 3 .

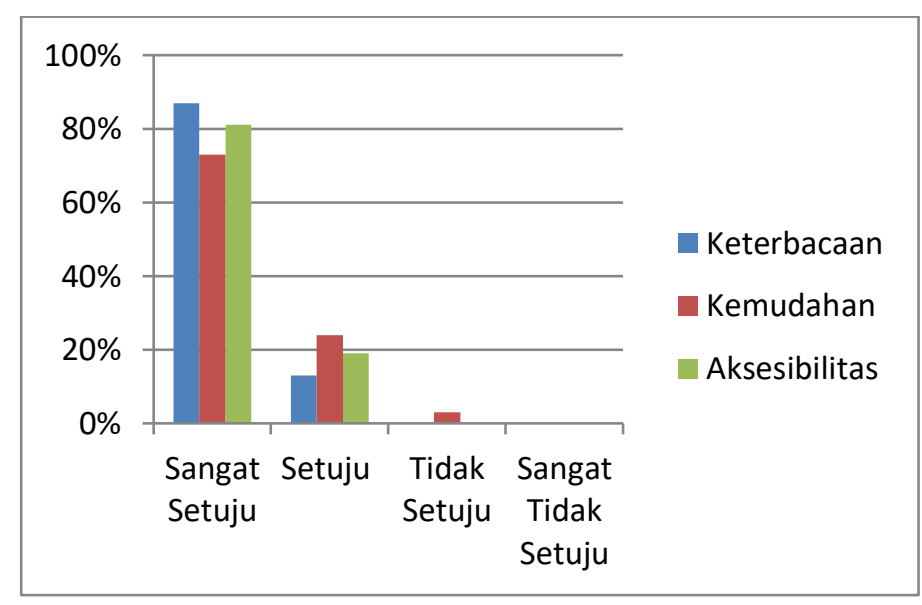

Gambar 3. Hasil respon siswa terhadap media pembelajaran

Pada umumnya siswa memberikan respon positif terhadap media pembelajaran yang dihasilkan. Siswa sangat terbantu memahami konsep yang diajarkan melalui media pembelajaran yang dihasilkan karena media yang digunakan tergolong sederhana dan mudah diaplikasikan. Akan tetapi, pada unsur kemudahan media digunakan terdapat 3\% siswa yang memberikan penilaian tidak setuju. Hal tersebut disebabkan pada media busur derajat terdapat dua skala pengukuran yang menurut mereka sulit dimengerti. Penggunaan dua skala dalam satu busur derajat belum mampu dipahami oleh beberapa siswa, terutama yang memiliki keterbatasan dalam mata pelajaran matematika. Oleh karena itu, tim mengupayakan pembuatan busur derajat yang lebih sederhana dengan menggunakan satu satuan pengukuran agar dapat mengakomodir siswa secara keseluruhan. 
Pembuatan media pembelajaran yang dilaksanakan di SMP YPK Tomer hanya difokuskan pada mata pelajaran matematika dan IPA. Hal tersebut disebabkan bidang keahlian dari tim pengabdian yang berlatarbelakang pendidikan matematika dan pendidikan sains. Selain itu, pada saat observasi mata pelajaran matematika dan IPA merupakan mata pelajaran yang dianggap sulit oleh siswa disertai tenaga pengajar dengan kualifikasi akademik yang dimiliki oleh guru belum sesuai (Rosyidah, Sudarmin, \& Kusoro, 2015; Shidiq, 2016; Suastra, 2010). Namun, pada saat sosialisasi dilaksanakan tim melakukan evaluasi kegiatan dengan mempertimbangkan respon positif yang diberikan oleh kepala sekolah dan guru SMP YPK Tomer. Meskipun media pembelajaran yang dibuat merupakan alat peraga untuk mata pelajaran matematika dan IPA, tetapi seluruh guru ikut dilibatkan dan mengikuti seluruh rangkaian sosialisasi. Perhatian yang begitu besar ditunjukkan oleh guru di SMP YPK Tomer membuat tim menambahkan materi umum tentang pentingnya penggunaan media dalam pembelajaran. Melalui pemaparan singkat mengenai penggunaan media, seluruh guru di SMP YPK Tomer mulai memikirkan perangkat media pembelajaran yang tepat digunakan untuk masing-masing materi yang diajarkan.

\section{Secara keseluruhan rangkaian} kegiatan pembuatan media pembelajaran teralaksana dengan baik dan lancar. Namun, terdapat beberapa hal yang menjadi bahan evaluasi kegiatan, yaitu:
Jadwal kegiatan yang mengalami kemunduran dari rencana awal menyebabkan setiap tahapan menjadi lebih singkat. Bahkan untuk tahap sosialisasi yang direncanakan pada minggu awal bulan november terpaksa mundur sampai minggu terakhir bulan november. Kemunduran jadwal tersebut menyebabkan tim melakukan konfirmasi berulang-ulang kepada pihak sekolah terkait pelaksanaan kegiatan.

- Jumlah peserta kegiatan yang melebihi perkiraan. Pada awalnya rencana kegiatan diikuti oleh 20 peserta guru dan siswa, tetapi perhatian yang begitu besar dari pihak sekolah untuk terlibat dalam kegiatan menyebabkan jumlah peserta mencapai 60 orang. Hal tersebut mengharuskan tim melakukan berbagai penyesuaian terkait masalah teknis dan non teknis, khususnya penyediaan ruangan dan konsumsi.

- Akses jalan menuju sekolah tergolong sulit dan menjadi tantangan tersendiri bagi tim. Hal tersebut mengakibatkan perjalanan menuju sekolah harus dimulai lebih awal.

- Proses pembuatan media pembelajaran yang dilaksanakan di sekolah menyebabkan tim harus menyiapkan berbagai alat yang hanya terdapat di Kota Merauke. Penggunaan alat yang tidak dimungkinkan di sekolah mengharuskan tim membuatnya di bengkel las, misalnya pembuatan rangka besi bangun ruang.

Kegiatan pengabdian kepada masyarakat sedianya merupakan sarana penerapan ilmu pengetahuan dan 
teknologi (IPTEK) yang dikembangkan di lingkungan perguruan tinggi di tengah-tengah masyarakat. Begitupun halnya dengan kegiatan pengabdian kepada masyarakat yang dilaksanakan di SMP YPK Tomer. Tim pengabdian dengan latar belakang akademik dan hasil penelitian yang dimiliki mencoba menerapkan IPTEK di SMP YPK Tomer dengan harapan kegiatan tersebut memiliki dampak bagi meningkatknya pengetahuan guru dan siswa serta dapat memecahkan berbagai permasalahan yang ada. Pembuatan media pembelajaran merupakan keniscayaan yang wajib dimiliki oleh guru agar dapat membantu berbagai kesulitan siswa dalam belajar. Namun, upaya tersebut bukanlah kegiatan instan yang dapat tercapai hanya beberapa kali tatap muka atau sosialisasi. Perlu ada suatu kegiatan yang berkelanjutan agar inti dari kegiatan pembuatan media pembelajaran dapat diimplementasikan secara menyeluruh.

Upaya yang dilakukan oleh tim agar pembuatan media pembelajaran merupakan kegiatan berkelanjutan di SMP YPK Tomer adalah sebagai berikut:

- Menyiapkan tutorial pembuatan media pembelajaran yang diperoleh dari berbagai referensi baik cetak maupun video. Tutorial tersebut bersifat pembimbingan mandiri yang dapat sewaktu-waktu digunakan tanpa ada pendamping.

Memberikan ruang diskusi bagi guru untuk menanyakan berbagai hal yang dipandang perlu melalui komunikasi telepon. Fasilitas telepon berupa jaringan telekomunikasi telah tersedia di Kampung Tomer sehingga memudahkan tim dalam melakukan monitoring keberlanjutan program pembuatan media pembelajaran.

\section{PENUTUP}

Kegiatan pengabdian kepada masyarakat di SMP YPK Tomer yaitu pembuatan media pembelajaran dengan melibatkan kearifan budaya lokal membuat pembelajaran konsep matematika dan IPA lebih mudah diterima dan dipahami oleh siswa. Guru juga menjadi lebih memahami bahwa pembuatan media pembelajaran tidak selamanya membutuhkan alat/bahan yang mahal bahkan dengan memanfaatkan potensi budaya lokal sekitar sekitar, siswa menjadi lebih menyadari pentingnya menjaga alam sekitar. Media pembelajaran matematika dan IPA yang dihasilkan, yaitu; 1 unit penggaris, 1 unit busur derajat, 1 unit rangka kubus, 1 unit rangka balok, 1 unit rangka prisma, 1 unit rangka limas, 1 unit rangka setengah bola, 1 unit rangka kerucut, 4 unit rangkaian alat uji konduktivitas sederhana, serta 4 unit alat penjernih air sederhana.

Adapun saran dalam kegiatan pengabdian ini adalah (1) Pemilihan alat/bahan dalam membuat media pembelajaran perlu memperhatikan aspek efektif dan efisiensi, (2) Guru hendaknya menggunakan media pembelajaran yang melibatkan nilai budaya lokal, (3) Kepala sekolah hendaknya memfasilitasi guru dalam mengembangkan media pembelajaran yang melibatkan nilai budaya lokal. 


\section{DAFTAR PUSTAKA}

Kencanawaty, G., \& Irawan, A. (2017). Penerapan Etnomatematika Dalam Pembelajaran Matematika Di Sekolah Berbasis Budaya. Ekuivalen-Pendidikan Matematika, 27(2), 169-175.

Kurniawan, H. E., Sarwanto, \& Cari. (2013). Pengembangan Modul Ipa SMP Berbasis Problem Based Learning Terintegrasi Pendidikan Karakter Pada Materi Getaran Dan Gelombang. Seminar Nasional Fisika dan Pendidikan Fisika "Pembelajaran Sains berbasis Kearifan Lokal." Universitas Sebelas Maret, Surakarta.

Mannan, M. N., Sopyan, A., \& Sunarno. (2015). Pengembangan Perangkat Pembelajaran Berbasis Kearifan Lokal Untuk Mengembangkan Karakter Positif Siswa SD. Jurnal Inovasi Dan Pembelajaran Fisika, 2(2), 141-146.

Rahayu, A., \& Sutikno, M. (2015). Pengembangan Media Pembelajaran Hukum Newton Menggunakan Fotonovela Berbasis Kearifan Lokal. In Prosiding Seminar Nasional Fisika (EJournal) SNF2015 (Vol. IV, pp. 33-38). Jakarta: Jurusan Fisika, Fakultas MIPA, Universitas Jakarta.

Rohaeti, E. E. (2011). TRANSFORMASI BUDAYA MELALUI PEMBELAJARAN MATEMATIKA BERMAKNA DI SEKOLAH. Jurnal Pengajaran
MIPA, 16(1), 139-147.

Rosyidah, A. N., Sudarmin, \& Kusoro,

S. (2015). PENGEMBANGAN MODUL IPA BERBASIS ETNOSAINS ZAT ADITIF DALAM BAHAN MAKANAN UNTUK KELAS VIII SMP NEGERI 1 PEGANDON KENDAL. Unne Scince Educational Journal, 4(2), 563569.

Saputra, A., Wahyuni, S., \& Handayani, R. D. (2016). Pengembangan Modul Ipa Berbasis Kearifan Lokal Daerah Pesisir Puger Pada Pokok Bahasan Sistem Transportasi Di SMP. Jurnal Pembelajaran Fisika, 5(2), 182-189.

Shidiq, A. S. (2016). PEMBELAJARAN SAINS KIMIA BERBASIS ETNOSAINS UNTUK MENINGKATKAN MINAT DAN PRESTASI BELAJAR SISWA. In Seminar Nasional Kimia dan Pendidikan Kimia (SNKPK) VIII (pp. 227-236). Surakarta: UNS.

Suastra, I. W. (2010). Model Pembelajaran Sains Berbasis Budaya Lokal Untuk Mengembangkan Kompetensi Dasar Sains dan Nilai Kearifan Lokal di SMP. Jurnal Pendidikan Dan Pembelajaran, 43(2), 8-16.

Supriyadi, Haeruddin, \& Nurjannah. (2016). Peningkatan kemampuan memecahkan masalah antara model penalaran kausal berbasis etnosains dan sains modern. JRKPF UAD, 3(2), 35-39. 